Dossiê: Desafios teológicos do Pluralismo Religioso - Artigo original (c)

\title{
A teologia católica face ao pluralismo religioso
}

\author{
The Catholic theology in the face of religious pluralism
}

Faustino Luiz Couto Teixeira *

\begin{abstract}
Resumo
O pluralismo religioso apresenta-se hoje com uma das questões decisivas para a teologia cristã, a ponto de delinear uma fisionomia nova para a reflexão em curso. Não há como fazer teologia no século XXI fora da interlocução criativa com os diversos caminhos religiosos que vão se apresentando no tempo atual. E a novidade está em reconhecer a dignidade da diferença, acolhendo esse pluralismo como um dado positivo no desígnio misterioso de Deus. O pluralismo deixa de ser visto como expressão negativa, como dado conjuntural ou expressão da cegueira dos humanos, para ser reconhecido como um fenômeno rico e fecundo. E a questão que se coloca para o cristianismo é o desafio de manter viva a sua identidade própria colocando-se à disposição para a escuta e o diálogo construtivo com as outras expressões religiosas. Partindo de considerações sobre os posicionamentos teológicos em torno do pluralismo religioso, o texto busca destacar os embaraços e desafios que se apresentam em particular para a cristologia e a eclesiologia.
\end{abstract}

Palavras-chave: Teologia. Pluralismo Religioso. Diálogo. Cristologia. Eclesiologia.

\begin{abstract}
Religious pluralism nowadays is one of the decisive issues for Christian theology to the point of delineating a new face for ongoing reflection. There is no way to do theology in the XXI century, except from the creative dialogue with the various religious paths that emerges now. In this way, the novelty is in recognizing the dignity of difference, welcoming this pluralism as a positive factor in the mysterious plan of God. Pluralism is not seen as a negative expression, as cyclical data or expression of human blindness, to be recognized as a rich and fruitful phenomenon. In addition, the question that arises for Christianity is the challenge of keeping alive its own identity by placing available for listening and constructive dialogue with other religious expressions. Starting from considerations of the theological positions around the religious pluralism, this article seeks to highlight the impediments and challenges facing in particular to Christology and ecclesiology.
\end{abstract}

Keywords: Theology. Religious Pluralism. Dialogue. Christology. Ecclesiology

\footnotetext{
Artigo recebido em 03 de agosto de 2015 e aprovado em 05 de novembro de 2015.

* Doutor em Teologia. Professor do Programa de Ciência da Religião da Universidade Federal de Juiz de Fora, MG. País de origem: Brasil. E-mail: fteixeira@uai.com.br
}

Horizonte, Belo Horizonte, v. 13, n. 40, p. 1736-1754, out./dez. - ISSN 2175-5841 
A história religiosa da humanidade é testemunha não só da busca tateante do mistério da Realidade última, mas também da pluralidade dos dons de Deus em busca do homem.

Claude Geffré

\section{Introdução}

Talvez um dos mais significativos desafios para o século XXI é o diálogo entre as religiões. Não há como desviar desse imperativo essencial de nosso tempo. Estamos todos envolvidos num mundo cada vez mais repleto de "outros", de identidades religiosas distintas que se encontram, que se vinculam ou que conflituam. As diferenças estão aí, mais diretamente visíveis e ao alcance. E podem ser objeto seja da preocupação, suspeita e altercação; seja da tolerância, reconciliação e diálogo. A grande aposta vai nessa segunda direção. Como indicou Marco Lucchesi, “o estrangeiro bate à nossa porta. Não há outro caminho senão o diálogo: na energia crescente, no vínculo de relação que o constitui. O diálogo é um tesouro precioso, uma zona de aventura, espanto e inquietação.” (LUCCHESI, 2014).

A abertura dialogal vem precedida pela acolhida benfazeja do pluralismo religioso. O diálogo requer essa disposição de um olhar receptivo à diversidade das crenças. O pluralismo deixa de ser visto apenas como um fato conjuntural, e passa a ser reconhecido em sua positividade, como pluralismo de princípio ou de direito. De forma tão convocadora, o papa Francisco destaca em sua Exortação apostólica, Evangelii Gaudium, que "a diversidade é bela" (EG 230). Trata-se de um momento novo, de um espírito novo, capaz de abertura e ousadia. Um espírito que provoca também a teologia a romper com esquemas tradicionais e pensar mais alto, arriscando novos caminhos. De fato, estamos diante de uma situação inédita, que suscita uma sensibilidade instauradora, capaz de reconhecer a presença de Deus e de sua graça nas diversas tradições religiosas. Esse é um horizonte que vem marcar os próximos passos da teologia: estar diante de um pluralismo insuperável. Como pontuou Claude Geffré, "os teólogos deverão cada vez mais suportar, 
intelectualmente, o enigma de uma pluralidade de tradições religiosas na sua irredutível diferença” (GEFFRÉ, 2013a, p. 6o).

A diversidade religiosa não é novidade no cenário mundial. A história vem marcada por essa riqueza, com as variegadas respostas dadas às grandes interrogações humanas pelas distintas religiões. O que ocorre no tempo atual é uma consciência nova da presença, vitalidade e riqueza das outras tradições religiosas (KNITTER, 2008, p. 15). É algo que provoca a consciência cristã, e também a teologia cristã. Vivemos uma situação planetária singular, marcada pelo traço intercomunicativo e interdependente. Isso provoca a necessidade de uma nova percepção do significado da multiplicidade das religiões.

Em âmbito da reflexão antropológica, Lévi-Strauss já tinha aventado sobre as resistências à diversidade das culturas. O ser humano tem grande dificuldade de lidar com a diversidade, sobretudo em razão do etnocentrismo, profundamente enraizado. Ao que parece, "a diversidade das culturas raramente surgiu aos homens tal como é: um fenômeno natural, resultante de relações diretas ou indiretas entre as sociedades; sempre se viu nela, pelo contrário, uma espécie de monstruosidade ou de escândalo” (LÉVI-STRAUSS, 1980, p. 53). Nesse texto, publicado originalmente em 1950, o pensador francês reagia ao etnocentrismo e propunha corajosamente a defesa da diversidade das culturas, num mundo "ameaçado pela monotonia". Enfatizava que esta diversidade devia "ser salva", e encarada "sem surpresa, sem repugnância e sem revolta", facultando um passo distinto e fundamental para a generosidade entre as culturas humanas (LÉVI-STRAUSS, 1980, p. 87).

A teologia também vem hoje provocada a acolher essa diversidade, e de modo particular, o pluralismo religioso, no sentido de levá-lo a sério, em sua significação mais positiva e desafiadora. É preciso ir ainda mais longe, nos adverte Claude Geffré, no sentido de uma teologia inter-religiosa, capaz de reinterpretar "a singularidade cristã em função das riquezas de ordem religiosa de que podem ser 
testemunhas as outras religiões” (GEFFRÉ, 2013a, p. 9); capaz também de favorecer uma nova inteligência do Mistério de Deus "a partir das luzes de que dão testemunho as diversas tradições religiosas da humanidade” (GEFFRÉ, 2013b, p. 90).

\section{A controvérsia em torno ao pluralismo religioso}

Acolher o pluralismo de princípio requer rever com seriedade toda uma herança teológica cristã fundada no exclusivismo ou na perspectiva do acabamento, ou seja, a ideia de que as outras religiões constituem "marcos de espera" para a sua realização no cristianismo. Este é um traço que está incrustrado na reflexão teológica cristã, e as resistências a quaisquer mudanças são bem vivas. Daí ter lembrado Jacques Dupuis sobre a importância de um salto qualitativo na reflexão teológica para que ocorra de fato uma dinâmica de abertura e colaboração mútua com as outras religiões. E fala em três aspectos essenciais: na purificação das memórias, da linguagem teológica e do entendimento teológico. Há que visar uma “mudança das mentalidades e dos espíritos, na verdade uma 'conversão' (metánoia) a Deus e aos outros por parte de todos que torne possível uma melhora nas relações”. Transformações devem igualmente ocorrer na linguagem, rompendo com o modo muitas vezes "ofensivo e deletério" com que se aborda as outras tradições religiosas e seus membros. E também no entendimento das outras tradições, visando uma “compreensão renovada no modo de pensar 'os outros' e seu patrimônio cultural e religioso”. (DUPUIS, 2004, p. 321).

Um olhar atento sobre o recorte teológico católico presente desde meados da década de 1940 sobre as outras religiões aponta esse traço da teoria do acabamento ou da realização. É uma visão que no Ocidente está relacionada a teólogos como Jean Daniélou, Henri de Lubac, Hans Urs von Balthasar e outros. Nesta perspectiva, os valores positivos das distintas religiões são explicitamente reconhecidos, mas destinados a encontrar o seu "acabamento" (remate) no cristianismo. Em verdade, “estas religiões não constituem, como antes, obstáculos 
a vencer, mas situam-se no plano de uma pedagogia divina como preparação ao evangelho. Nesse sentido, constituem 'pierres d'attente' (marcos de espera) e a missão da igreja, sua inserção na pedra angular que é Cristo”. (TEIXEIRA, 2012, p. 30).

Mesmo teólogos de ponta, como Karl Rahner, não escaparam a tal perspectiva, ainda que com nuances novidadeiras. No âmbito do magistério eclesial, a Declaração Dominus Iesus (DI), da Congregação para a Doutrina da Fé (CdF, 2000), veio “consagrar” essa posição teológica (TEIXERIA, 2000). Como exemplo, a rígida separação entre a fé teologal e a crença nas outras religiões. Na visão defendida pela $\mathrm{CdF}$, a fé teologal consiste na "aceitação da verdade revelada por Deus Uno e trino", enquanto as crenças traduzem uma "experiência religiosa ainda à procura da verdade absoluta e ainda carecida do assentimento a Deus que se revela" (DI 7) (CTI, 1997)1. A Declaração da CdF não exclui a presença da graça divina nos adeptos das outras religiões, mas reitera que os mesmos encontram-se objetivamente numa "situação gravemente deficitária, se comparada com a daqueles que na Igreja têm a plenitude dos meios de salvação” (DI 22). Em semelhante perspectiva, também a Notificação da CdF, de janeiro de 2001, em torno do livro de Jacques Dupuis: Verso una teologia cristiana del pluralismo religioso (1997). Na proposição de número 3, a precisa defesa da teologia do acabamento: "É conforme a doutrina católica afirmar que as sementes da verdade e bondade existentes nas outras religiões constituem uma certa participação na verdade contida na revelação de/em Jesus Cristo”. E estes elementos de verdade e bondade, ainda segundo a Notificação, derivam em última instância da mediação fontal de Jesus Cristo (CdF, 2006, p. 550).

Reagindo ao posicionamento da CdF com a Dominus Iesus, o teólogo Jacques Dupuis assinala que o limite do documento foi tomar todas as religiões do mundo em bloco, sem proceder as devidas distinções, como no caso da

\footnotetext{
${ }^{1}$ Em linha de sintonia com tal perspectiva, a posição defendida pela Comissão Teológica Internacional (CTI, 1997) no Documento: $O$ cristianismo e as religiões, publicado em 1997: “As religiões falam 'do` Santo, 'de` Deus, 'sobre` ele, 'em seu lugar' ou em 'seu nome'. Apenas na religião cristã é Deus mesmo quem fala ao homem em sua palavra".
} 
especificidade das religiões abraâmicas. O resultado acaba sendo ofensivo com respeito ao judaísmo e ao islã, só para ficar num exemplo. Segundo Dupuis, “o único papel que a Dominus Iesus dispõe-se a conceder aos elementos das outras tradições religiosas que 'procedem de Deus' consiste no fato de serem “ocasiões ou pedagogias que estimulam os corações dos homens a se abrirem à ação de Deus” (DUPUIS, 2014, p. 108)². A distinção operada pela CdF acaba levando a uma lógica que reafirma o tradicional axioma "extra ecclesiam nulla salus" (fora da Igreja não há salvação). Segundo Dupuis, afirmações assim gerais acabam ofendendo a vida religiosa dos membros das outras tradições e carecem de plausibilidade, pois "não há nenhuma justificação bíblica para refutar a extensão da existência da fé divina aos membros das outras religiões”. (DUPUIS, 2014, p. 77).

Mediante um olhar atento, verifica-se que a lógica do acabamento, com nuances diversificadas, vigora em muitos posicionamentos teológicos católicos, mesmo entre os autores que buscam ampliar sua reflexão com os novos desafios do tempo. É o que se percebe na resistência à acolhida do pluralismo religioso de princípio. Já a Dominus Iesus tinha reagido a tal perspectiva, assinalando que ela colocaria em questão o "perene anúncio missionário" (DI 4). Como justificativa, o temor do relativismo. Os argumentos firmados na DI acabaram delineando os posicionamentos teológicos que se seguiram, de forma consciente ou não. Em obra publicada originalmente em 2008, o teólogo e cardeal Walter Kasper contesta aqueles que defendem o pluralismo religioso de princípio. Sinaliza que esta posição encontra hoje um grande consenso, mas "não é conciliável nem com a fé cristã nem com as religiões judaica e muçulmana”. E adverte: “Aqueles que buscam realizar a paz entre as religiões baseando-se na tese do pluralismo religioso, devem primeiramente abolir as três religiões monoteístas”. (KASPER; DECKERS, 2009, p. 276)3. Também o teólogo espanhol Andrés Torres Queiruga resiste ao tema,

\footnotetext{
2 Uma tal assimetria foi também contestada por Christian Duquoc (2008) , ao abordar a pertença religiosa anônima de Karl Rahner. São procedimentos que segundo Duquoc não explicam "a extraordinária diversidade das religiões", conservando delas "apenas sua capacidade de abrir-se positivamente àquilo que ignoram ou, talvez, até mesmo combatam".

${ }^{3} \mathrm{Em}$ outra obra, Kasper (2009) indica que a relação dialógica e diaconal envolve também um convite, destinado às outras religiões e culturas, de encontro com Jesus, de modo a favorecer, "mediante a participação na sua plenitude, a própria plenitude e perfeição (via eminentiae)".
} 
advertindo que por trás da defesa do pluralismo de princípio reside uma lógica "voluntarista", como se o mesmo estivesse vinculado a um "querer misterioso de Deus" e não a uma "inevitabilidade criatural" (QUEIRUGA, 2010, p . 290). Sem abrir espaço para qualquer exclusivismo, resiste igualmente ao que chama de universalismo indiferenciado. Defende um “universalismo assimétrico”, reagindo ao risco de uma equivalência reveladora entre as religiões. Busca marcar o traço da diferença que vigora entre as religiões e suas “"gradações’ objetivas” (QUEIRUGA, 2010, p. 360). Em semelhante perspectiva, Jacques Dupuis também defende uma assimetria quando aborda a complementaridade entre as religiões. Fala em reciprocidade, mas complementa com a ideia de assimetria. Reconhece a presença de "valores adicionais e autônomos de verdade e graça" nas outras religiões, sem porém equipará-las ao cristianismo, em razão da "transcendência insuperável da revelação e da autocomunicação de Deus na pessoa e na obra de Jesus Cristo” (DUPUIS, 2004, p. 320; CdF, 2006)4 Também Claude Geffré, no prefácio de sua obra De babel a pentecostes, com data de agosto de 2005, mostra certo titubeio ao tratar o tema do pluralismo de princípio. Assinala que é "inábil falar de um pluralismo de jure ou de direito", mas reconhece como fundamental reiterar um "misterioso querer de Deus relacionado com aquilo que a Revelação nos ensina a propósito da vontade de Deus de salvação universal”. (GEFFRÉ, 2013a, p. 7)5.

Um dos teólogos pioneiros na defesa de um pluralismo de princípio foi Edward Schillebeeck. Em obra que coroa o seu vasto projeto cristológico, Humanidade, a história de Deus (1989)6, ele levanta a questão decisiva: se o pluralismo das religiões é fenômeno de fato ou de princípio. Sua resposta é incisiva, e vai na direção da defesa desse pluralismo como "riqueza” a ser "saudada por

\footnotetext{
${ }^{4}$ A ideia de inclusão da expressão "assimétrica" na abordagem da complementariedade religiosa entre as religiões foi sugestão do teólogo Gerald O'Collins (2013), companheiro de Dupuis na Gregoriana. Uma inserção que se explica no contexto difícil da notificação da CdF em torno da obra de Jacques Dupuis: "Verso una teologia Cristiana del pluralismo religioso" (janeiro de 2001). A notificação era bem clara na proposição 3: "A revelação histórica de Jesus Cristo oferece tudo o que é necessário para a salvação do homem e não necessita ser complementada pelas outras religiões": CdF, 2006, p. 550.

${ }^{5}$ De novo aqui a sombra da Dominus lesus (DI) atuando como barreira para uma ampliação do olhar. Curiosamente, Geffré sublinha que a DI significou uma "salutar advertência a certos teólogos", que na busca por um diálogo inter-religioso acabaram "tentados a questionar a unicidade e a universalidade salvífica do mistério de Cristo", embora reconheça também que a Declaração da CdF, em sua "obsessão com o relativimo", acabou obedecendo "demais a uma lógica de absolutismo na sua maneira de compreender tanto o diálogo inter-religioso como o diálogo ecumênico". Gefré (2013).

${ }^{6}$ Traduzida no Brasil com o título: História humana, revelação de Deus,(1994).
} 
todos” e não eliminável historicamente. As outras tradições religiosas guardam aspectos de beleza e positividade que não se encontram na específica experiência do cristianismo (SCHILLEBEECKX, 1994a, p. 212 e 215-216). Na trilha aberta pelo teólogo belga, outros vieram reforçar essa mesma posição, como Jacques Dupuis (DUPUIS, 1999, p. 26 e 526-528; DUPUIS, 2004, p. 316-318), Michael Amaladoss (AMALADOSS, 1993, p. 126 e 128); Claude Geffré (GEFFRÉ, 2004, p. 134-138; GEFFRÉ, 2013a, p. 52 e 102) e Roger Haight (HAIGHT, 2003, p. 456). Esses autores comungam de uma visão semelhante, que identifica o pluralismo religioso como um "desígnio misterioso de Deus", cujo significado escapa largamente a qualquer compreensão humana. A pluralidade do fenômeno religioso é percebida como um valor duradouro, que em verdade concorre para enriquecer a compreensão e a experiência de um Mistério que sempre advém. Não há por que temer esta diversidade, ela na verdade expressa "um adorno do espírito humano e de sua longa história. É algo a ser celebrado, não lamentado" (DALAI LAMA, 2014, p. 199).

\section{A teologia cristã desafiada pelo pluralismo}

Para além de uma lógica exclusiva de identidade, a teologia cristã deve deixar-se habitar pela dinâmica da diferença. Romper com a imagem problemática que identifica a diferença como indigna de Deus. Esse novo procedimento é fundamental para acolher com dignidade o pluralismo. É o desafio que se apresenta hoje com radicalidade para o cristianismo. O problema veio colocado com pertinência por Christian Duquoc:

Como compreender que o cristianismo possa deixar subsistir uma exterioridade positiva na sua relação com Deus em Jesus ? Ou em outras palavras: como o cristianismo pode pensar a própria identidade admitindo a positividade das diferenças religiosas? (DUQUOC, 1985, p. 135).

Uma abordagem honesta do cristianismo não coaduna em hipótese alguma com uma perspectiva absolutista ou exclusivista. Ao contrário, a acolhida da 
diversidade está radicalmente implicada no coração do cristianismo. A relação do cristianismo com as outras religiões deve ser caracterizada por uma atitude de abertura e justamente porque o Deus de Jesus constitui um símbolo de abertura, um Mistério que integra "a inquietação, o rumor e a riqueza do plural” (GESCHÉ, 2004, p. 172). O teólogo Edward Schillebeeckx identifica o fundamento desta abertura nos desdobramentos da própria prática reinocêntrica de Jesus, de uma prática que aponta sempre "para além de si rumo ao próprio Deus" (SCHILLEBEECKX, 1994)7. Indica com acerto que o cristianismo em sua singularidade está intimamente ligado a uma particularidade histórica, que envolve regionalidade e limite. Assinala que

a revelação de Deus em Jesus, tal como no-la prega o evangelho cristão, não significa absolutamente que Deus absolutize uma particularidade histórica (ainda que seja a de Jesus de Nazaré). Sabemos, por essa revelação de Deus em Jesus, que nenhuma singularidade histórica pode ser chamada de absoluta e, por isso, por causa da relatividade presente em Jesus, todo homem pode se encontrar com Deus também fora de Jesus, a saber, em nossa história mundana e nas muitas religiões que nela surgiram. (SCHILLEBEECKX, 1994a, p. 214) ${ }^{8}$.

Na base da abertura dialogal há, portanto, um “paradoxo da encarnação”, ou seja, a presença do Absoluto numa particularidade histórica. Essa presença "nos convida a não qualificar de absoluto o cristianismo como uma religião exclusiva de todas as outras" (GEFFRÉ, 2013a, p. 131). Em semelhante linha de reflexão, o teólogo Adolphe Gesché destacou elementos imanentes no próprio cristianismo que impedem uma consideração exclusivista desta tradição. Dentre os “campos de imanência" apontou, entre outros, a tradição da teologia negativa e mística, a reserva escatológica, a doutrina trinitária e a luta contra a idolatria. Reconhece nesse último âmbito o campo de imanência mais misterioso, em que se aponta o necessário distanciamento entre Deus e os humanos. Algo que o próprio Cristo chamou a atenção, indicando que o Pai é sempre maior (Jo 14,28). E argumenta:

\footnotetext{
7 Como indica Schillebeeckx (1994a, p. 214), "a definição de Deus que aparece em Jesus reenvia, consequentemente, a "outro", a 'alguém ' que escapa a toda identificação histórica, incluída aquela de Jesus, confessado como sendo o Cristo. Se não fosse assim, a mística cristã, que faz parte integrante da tradição confessante, perderia o seu sentido" (SCHILLEBEECKX, 1994b, p. 278).

${ }^{8}$ Ver também: Duquoc, 1985, p. 136-137.
} 
Mesmo na religião da encarnação de Deus, Jesus não cessa de lembrar que é para o Pai, e não para ele, que devemos nos voltar, para aí encontrar exatamente o distanciamento e a mediação que salvam do imediato. Yves Congar relembrou muitas vezes que em nossa teologia pode haver um cristocentrismo que não é cristão. É um dos sentidos do segredo messiânico. Ao se abolutizar, o cristianismo se torna idolatria, e essa contrafação se volta contra ele mesmo e contra sua lógica, que consiste exatamente em ser luta contra a idolatria, para que a salvação não seja vã. A idolatria é exatamente a recusa do distanciamento, que se perderia com a pretensão do acesso total, saturador, de fusão, absoluto. (GESCHÉ, 2004, p. 187).

A abertura ao pluralismo de princípio envolve transformações profundas no modo como a teologia cristã trabalha a cristologia. Sobretudo a recuperação do senso misterioso e transcendente de Deus. Em sua clássica obra em torno de uma teologia cristã do pluralismo religioso, Jacques Dupuis reagiu contra o risco do cristomonismo: a tendência de uma excessiva concentração cristocêntrica do mistério da salvação. Risco muitas vezes denunciado pela tradição oriental. Daí sua preocupação em evitar a todo custo atribuir o qualificativo de 'absoluto' seja ao cristianismo ou mesmo a Jesus Cristo. E a razão aventada é que este atributo reserva-se à Realidade última ou ao Ser Infinito. Nenhuma realidade finita, nem mesmo a do Filho-de-Deus-feito-homem pode esgotar o mistério divino (DUPUIS, 1999, p. 346 e 390; DUPUIS, 2004, p. 211; DUPUIS, 2014, p. 95-96)9.

Uma atenção especial deve ser concedida à linguagem teológica adotada, evitando o vocabulário deletério com respeito aos outros. Um cuidado que deve ser adotado ao falar da figura de Jesus de Nazaré. Visando o diálogo, deve-se atender prioritariamente a proposta reveladora de Jesus de Nazaré, e não tanto a sua pessoa individual (QUEIRUGA, 2001, p. 345-346). Esse é o caminho adotado por muitos cristãos na Ásia, para os quais "proclamar a Cristo significa antes de tudo viver como ele, no meio dos próximos e vizinhos que não têm a mesma fé e não são da mesma confissão nem convicção e, pela força de sua graça, fazer o que ele fez. Uma proclamação pelo diálogo e pelos atos” (FABC, 2000, p. 42).

\footnotetext{
${ }^{9}$ Como assinalou Paulo VI na Exortação Apostólica Evangelii nuntiandi (1975), só o Reino é absoluto (EN 8). E também João Paulo II, na Carta Apostólica Fides et Ratio (1998): "Só Deus é o Absoluto" (FR 80).
} 
O teólogo Andrés Torres Queiruga sublinha a importância de uma séria revisão do cristocentrismo, evitando frases que hoje revelam-se altamente problemáticas como: "não existe conhecimento de Deus a não ser em Jesus Cristo". São expressões que perdem sua plausibilidade no tempo atual. Elas até podem manter seu sentido

em uma linguagem interna, de natureza imediatamente 'confessante', todavia, em rigor, devem ser eliminadas, não só por serem psicologicamente ofensivas para os demais, mas por serem objetivamente falsas, pois implicam a negação de toda verdade nas demais religiões, incluindo o Antigo Testamento. (QUEIRUGA, 2001, p. 347-348).

Vale aqui uma observação sobre essa questão da linguagem “confessante”. $\mathrm{Na}$ trajetória do cristianismo, a linguagem dos discípulos de Jesus veio muitas vezes marcada por esse traço absoluto. Trata-se, como diz Dupuis, de uma linguagem de "sobrevivência", uma linguagem performativa, "destinada a exortar os discípulos a um seguimento entusiasmado” (DUPUIS, 2004, p. 218). Para os fieis cristãos, o Absoluto ganha uma fisionomia concreta em Jesus, e só para eles, Jesus apresenta-se como a Palavra e o Caminho. A confissão essencial feita pelos cristãos de que Jesus é o Cristo e que nele Deus se revelou de modo decisivo é uma “afirmação existencial e não uma frase objetiva e objetivável”. Trata-se de um enunciado de fé, mas não de uma afirmação baseada numa constatação que pode ser verificada para além da fé professada (SCHILLEBEECKX, 1994, p. 190-191; PANIKKAR, 1994, p. 17; KUNG, 1999, p. 286; KNITTER, 2011, p. 164). ${ }^{10}$

A revisão do cristocentrismo não coloca em questão a identidade cristã, que mantem sua força viva, mas a afirmação desta identidade não comporta expressões exclusivistas que acabam por negar o significado positivo das outras tradições religiosas no misterioso desígnio de Deus. Segundo Dupuis, “afirmações absolutas e exclusivas sobre Cristo e sobre o cristianismo que reivindicassem a posse exclusiva da auto-afirmação de Deus ou dos meios de salvação distorceriam e

\footnotetext{
${ }^{10}$ Há algo de peculiar na linguagem religiosa, como indica Schillebeeckx (1994b, p.268), e isto pode ser observado na linguagem neotestamentária. Trata-se de uma linguagem performativa da confissão de fé, com uma estrutura semântica diversa daquela objetivante da ciência. É um discurso que se aproxima do linguajar dos amantes.
} 
contradiriam a mensagem e a imagem cristãs" (DUPUIS, 2004, p. 15). A realidade plural das religiões não está fora da atmosfera da acolhida benfazeja de Deus, mas encontra "sua última fonte num Deus que é amor e comunicação".

Na linha da argumentação da CdF na Notificação sobre a obra de Jacques Dupuis, Jesus Cristo vem apresentado como "o mediador, cumprimento e plenitude da revelação”, fornecendo tudo o que é necessário para a salvação (CdF II, n.3 - 2006, p. 550). Reagindo a tal perspectiva, Jacques Dupuis assinala que a expressão "mediação fontal” - utilizada na Notificação da CdF (n. 4) - é um pouco equivocada. Argumenta que

o mediador não é a nascente fontal dos elementos de verdade e bondade que se encontram nas outras tradições religiosas. A nascente fontal ou suma causa é Deus Pai; Jesus Cristo age enquanto mediador entre Deus e a humanidade em nome e sob a iniciativa do Pai. Em última análise, é de Deus que derivam os elementos de verdade e bondade presentes nas tradições. (DUPUIS, 2014, p. 139).

Também o documento Diálogo e Anúncio, do Pontifício Conselho para o diálogo Inter-Religioso, avança nessa direção quando reconhece que o mistério de salvação atinge os fieis de outras tradições religiosas através de "caminhos por Deus conhecidos", e isto mediante a "prática daquilo que é bom nas suas próprias tradições religiosas, e seguindo os ditames da sua consciência” (DA 29).

Não há dúvida sobre o lugar ocupado por Jesus na tradição cristã, sendo reconhecido pelos fieis desta tradição como constitutivo de sua salvação, ou seja, o "mediador da consciência cristã da vida no Espírito". Mas como lembra Roger Haight, as Escrituras judaica e cristã atestam que

Deus como Espírito está presente e atuante no mundo, em prol da salvação humana, desde os primórdios, sem nexo causal com a manifestação histórica de Jesus. Por conseguinte, Jesus é constitutivo e a causa da salvação dos cristãos, por ser o mediador da consciência cristã da vida no Espírito. Mas Jesus não é constitutivo da salvação em termos universais. Pelo contrário, uma cristologia do Espírito, ao reconhecer que 
o Espírito é operativo externamente à esfera cristã, está aberta a outras mediações de Deus. (HAIGHT, 2003, p. 523).11

Uma vez reconhecido que o fundamento universal da salvação é Deus como Espírito, "normativamente revelada em Jesus, mas igualmente presente em outras religiões”, abre-se espaço para a plausibilidade de outros canais da presença gratuita de Deus, que pode ocorrer num evento, num livro, numa práxis ou ensinamento, e não unicamente numa pessoa. Como revela Haight, "religiões outras que não o cristianismo medeiam, verdadeira e realmente, a presença de Deus, de sorte que Deus é precisamente encontrado em diversos e diferentes caminhos". (HAIGHT, 2003, p. 477).

O fato de estarmos animados pela convicção de que Deus age também na história através de outras mediações não prejudica o compromisso que assumimos como cristãos, bem como nossa compreensão da riqueza da experiência de Deus mediada por Jesus. O que ocorre é apenas uma ampliação do olhar, com o reconhecimento de que Jesus não é o único caminho da vida para Deus. Como mostrou Schillebeeckx, "Jesus não só revela Deus, mas também o esconde, uma vez que surge em humanidade criada e não-divina. E assim, como homem, ele é um ser histórico, contingente, limitado, que não pode absolutamente representar toda a riqueza de Deus" (SCHILLEBEECKX, 1994a , p. 26). Assim sendo, a manifestação de Deus em Jesus não provoca uma clausura na história da religião, nem um termo na dinâmica renovadora dos dons de Deus no tempo. O processo revelador está aberto enquanto houver história.

Assim como no âmbito da cristologia, também encontramos na reflexão eclesiológica traços de uma perspectiva que dificulta a abertura dialogal e a acolhida do pluralismo (QUEIRUGA, 2010, p. p.366-369; 2001, p. 318-324) ${ }^{12}$. Tanto a teologia como a mentalidade usual dos cristãos continuam ainda

\footnotetext{
${ }^{11}$ Uma posição semelhante vem defendida por Schillebeeck, como assinalou Roger Haight (2008, p.104), com a indicação de Jesus não como constitutivo da salvação mas como "o mediador da salvação especificamente cristã"

${ }^{12}$ Podíamos também acrescentar aqui os pressupostos que regem a reflexão teológica cristã sobre a revelação. Daí a proposta sugerida por Torres Queiruga (2010, p.366-369; 2001, p.318-324) de repensar a revelação numa perspectiva nova, aberta ao futuro, e que não se confunde com clausura. Ou seja, uma perspectiva que vá além do traço milagroso e exclusivista da revelação.
} 
trabalhando consciente ou inconscientemente com os pressupostos de um posicionamento mais reticente. A força e o peso das afirmações doutrinais sobre a igreja acabam atemorizando ou bloqueando uma reflexão eclesiológica mais aberta sobre o pluralismo religioso. A busca da fidelidade ao passado acaba sendo preponderante e o "terror em face do risco inerente a qualquer interpretação provoca a repetição das fórmulas tradicionais" (DUCQUOC, 2001, p. 190). Permanece bem acesa na reflexão teológica uma terminologia que é devedora de um eclesiocentrismo problemático. Algumas expressões do repertório eclesiológico provocam desconforto no campo do diálogo com as outras religiões, exercendo um efeito negativo, como é o caso da noção de "Povo de Deus". Trata-se de um termo que assinala a especial eleição do povo de Israel por Deus, que foi ampliada e concretizada na igreja. Falar no tempo atual de um povo eleito por Deus, como se os outros povos fossem excluídos da eleição, torna-se problemático. Não é sem razão que alguns teólogos têm sugerido o abandono dessa terminologia, no sentido de resguardar a não discriminação do amor (QUEIRUGA, 1998, p. 35). Na verdade, como sublinhado no manifesto do I Encontro da Assembleia do Povo de Deus, no ano de 1992 em Quito (Equador), o "Povo de Deus são muitos povos” (TEIXEIRA, 1997, p. 149). Outra expressão problemática é a que fala em “ordenação” dos não cristãos ao Povo de Deus. Esta expressão, presente na Lumen Gentium, n. 16 (Vaticano II), com base em Tomás de Aquino, é recorrente mesmo nos textos dos teólogos inclusivistas que trabalham o tema da teologia do pluralismo religioso (GEFFRÉ, 2004, p. 159; DUPUIS, 2004, p. 268). Também a expressão "reino de Deus" provoca reservas no contexto do diálogo inter-religioso e de seus desdobramentos teológicos, sobretudo em razão de sua inscrição histórica, relacionada à esperança de Israel e ao campo restrito do cristianismo (DUPUIS, 1999, p. 456; DUQUOC, 2008, p. 89). Pode-se ainda mencionar a definição corrente de igreja como "sacramento universal da salvação", presente na Lumen Gentium, n. 48, e da "necessidade" da igreja para a salvação (Lumen Gentium, n. 14). Sobre essa questão discorreu Jacques Dupuis, com observações bem apropriadas: 
O fato de a Igreja ser o sacramento do Reino de Deus universalmente presente na história não implica necessariamente que ela exerça uma atividade de mediação universal da graça em favor dos membros das outras tradições religiosas que entraram no Reino de Deus respondendo ao convite de Deus pela fé e pelo amor. (DUPUIS, 1999, p. 485).

Nada mais problemático do que restringir a dignidade das outras tradições religiosas assinalando que elas "objetivamente se encontram numa situação gravemente deficitária, se comparada com a daqueles que na Igreja têm a plenitude dos meios de salvação" (DI 22). Isto é o que mais irrita teólogos como Jacques Dupuis, envolvidos no diálogo inter-religioso. Trata-se de algo que objetivamente ofende aos outros, revelando uma perspectiva teológica curta e ensimesmada. Como assinala Dupuis, o conceito de salvação apresentado pela Dominus Iesus (DI) revela um estreitamento de horizontes, reiterando seu traço exclusivo de consciência da verdade. O que permanece ausente, e que é essencial, é o traço do amor, do agápe. E esse é o traço fundamental apontado por Jesus para indicar o caminho da salvação (Mt 25, 31-46 e 1Jo 4,16). O que fundamentalmente conta para a salvação, sublinha Dupuis, não é o acesso à plenitude da verdade, nem o beneficiamento dos meios de salvação confiados por Jesus à Igreja, mas o exercício do amor (DUPUIS, 2014, p. 114-115). Para Dupuis,

as obras do amor ou o agápe em ação são, do ponto de vista cristão, o sinal de que Deus entrou na vida de uma pessoa revelando e manifestando a si mesmo - não importa quanto 'anonimamente `ou secretamente; e não importa quanto imperfeita possa permanecer no sujeito a consciência de Deus que interveio dessa maneira. Elas também são o sinal que a pessoa respondeu positivamente à intervenção divina na sua vida. (DUPUIS, 1999, p. 447).

\section{Conclusão}

Um dos traços mais bonitos do Concílio Vaticano II no que tange à abertura inter-religiosa foi o reconhecimento feito pelo Decreto Ad Gentes (AG) sobre a atividade missionária da igreja, da presença de verdade e graça nas outras tradições religiosas (AG 9). Essa foi uma guinada fundamental do Concílio, o que equivale a dizer que "Deus está se revelando e exercendo sua salvação em todas e em cada 
uma das religiões, sem que jamais algum homem ou mulher tenham sido privados da oferta de sua presença amorosa” (QUEIRUGA, 2001, p. 319). O mesmo Concílio abriu sendas inovadoras com o reconhecimento da liberdade de consciência, também no campo da religião ( $\mathrm{DH}$ 3). Foi o passo decisivo para o respeito ao destino espiritual de cada ser humano.

O diálogo verdadeiro abre sempre espaço ao Espírito e ao seu trabalho revelador. É o Espírito que mantém sempre aceso o inacabamento e a dinâmica incessante de movimento em direção ao novo e ao inusitado. As práticas equivocadas da igreja católica em seu longo percurso histórico revelaram na verdade o "quanto é perigoso, sob pretexto de ser detentora da Palavra de Deus e de ser assistida pelo Espírito, ficar no centro que organiza a ligação dos fragmentos, ou seja, ocupar visivelmente o lugar de Deus" (DUQUOC, 2008, p. 155). O trabalho do Espírito consiste em manter esse lugar vazio ou inacabado até que o tempo ganhe sua completude. Toda a dinâmica histórica que pontua a nossa relação com Deus vem protegida por uma reserva escatológica. Não há como romper o dado fragmentário e provisório de nossa relação com o Mistério sempre maior.

As religiões devem deixar-se perpassar pelo toque da transcendência e do enigma que envolvem todo o mundo habitado. Desconhecer a verdade salvífica que atua nas religiões é distanciar-se do Deus da criação. O verdadeiro encontro com Deus, como sublinha Roger Haight,

se dá em um encontro com o mistério. Nem Jesus nem o cristianismo medeiam uma posse plena de Deus. Sem um senso do mistério transcendente de Deus, não se esperará conhecer mais a respeito dele a partir do que é transmitido a nós, seres humanos, por meio de outras revelações e religiões. (HAIGHT, 2003, p. 479)

Em bela entrevista concedida por papa Francisco a Eugenio Scalfari ele sublinhou que o mundo vem percorrido por estradas que nos aproximam e distanciam. Mas o que é mais importante é que elas nos conduzam ao Bem. Esse é o passo fundamental (FRANCESCO; SCALFARI, 2013, p. 55). Não há por que 
temer a pluralidade das religiões. O problema não está aí, mas no risco das querelas e tensões inter-religiosas. Contra as guerras de religião o melhor antídoto é o caminho dialogal, longe de qualquer proselitismo. O diálogo que se firma

não para reduzir o outro, não para convencer de que está errado, mas para aprender com ele, num caminho novo. O diálogo é um ponto de luz, uma porta de saída para o impasse, um gesto solidário. E o centro do diálogo reside na acolhida, na beleza do rosto que contemplo, no olhar do outro que me indaga e me convida a mover os lábios. (LUCCHESI, 2014).

A teologia do pluralismo religioso firma-se nesse caminho de conversação essencial com os outros, reconhecidos como amigos e interlocutores dignos, portadores de luzes nessa peregrinação ao horizonte do Mistério que nos aguarda. E o teólogo cristão em particular vem provocado a responder essa indagação fundamental, num contexto de rica diversidade cultural e religiosa: Como viver e garantir a identidade processual numa dinâmica de abertura, atenção e cortesia ao mundo do outro?

\section{REFERÊNCIAS}

AMALADOSS, Michael. Rinnovare tutte le cose. Dialogo, pluralismo ed evangelizzazione in Asia. Roma: Arkeios, 1993.

COMISSÃO Teológica Internacional. O cristianismo e as religiões. São Paulo: Loyola, 1997.

CONGREGAÇÃO para a Doutrina da Fé (CdF). Declaração Dominus Iesus. Sobre a unicidade e universalidade salvífica de Jesus Cristo e da Igreja. São Paulo: Paulinas, 2000.

CONGREGATIO pro Doctrina Fidei (CdF). Documenta Inde a Concilio Vaticano

Secundo. Expleto edita (1966-2005). Città del Vaticano: Libreria Editrice Vaticana, 2006.

DOCUMENTOS do Concílio Ecumênico Vaticano II (1962-1965). São Paulo: Paulus, 1997.

DUQUOC, Christian. Un Dio diverso. 2 ed. Brescia: Queriniana, 1985.

DUQUOC, Christian. “Credo la chiesa”. Precarietà istituzionale e regno di Dio. Brescia: Queriniana, 2001.

DUQUOC, Christian. O único Cristo. A sinfonia adiada. São Paulo: Paulinas, 2008. 
DALAI LAMA. Uma ponte entre as religiões. Por uma verdadeira comunhão da fé. São Paulo: Martins Fontes, 2014.

DUPUIS, Jacques. Rumo a uma teologia cristã do pluralismo religioso. São Paulo: Paulinas, 1999.

DUPUIS, Jacques. O cristianismo e as religiões. Do desencontro ao encontro. São Paulo: Loyola, 2004.

DUPUIS, Jacques. Perché non sono eretico. Teologia do pluralismo religioso: le acuse, la mia difesa. Bologna: EMI, 2014.

FEDERAÇÃO das Conferências Episcopais da Ásia (FABC). Documento de Síntese: O que o Espírito diz às Igrejas. Sedoc, Petrópolis, v. 33, n. 281, p. 38-50, julho-agosto 2000.

FRANCESCO, Papa; SCALFARI, Eugenio. Dialogo tra credenti e non credenti. Torino: Einaudi/La Repubblica, 2013.

FRANCISCO. Evangelii Gaudium [A alegria do evangelho]. São Paulo: Paulus; Loyola, 2013.

GEFFRE, Claude. Crer e interpretar. A virada hermenêutica da teologia. Petrópolis: Vozes, 2004.

GEFFRÉ, Claude. De babel a pentecostes. Ensaios de teologia inter-religiosa. São Paulo: Paulus, 2013a.

GEFFRÉ, Claude. Le christianisme comme religion de l'évangile. Paris: Cerf, $2013 b$.

GESCHÉ, Adolphe. A destinação. São Paulo: Paulinas, 2004.

HAIGHT, Roger. Jesus, símbolo de Deus. São Paulo: Paulinas, 2003.

HAIGHT, Roger. O futuro da cristologia. São Paulo: Paulinas, 2008.

JOÃO PAULO II. Carta Apostólica Fides et Ratio. São Paulo: Loyola, 1998.

KASPER, Walter. Vie dell' unità. Prospettive per l'ecumenismo. Brescia: Queriniana, 2006.

KASPER, Walter; DECKERS, Daniel. Al cuore della fede. Le tappe di una vita. Cinisello Balsamo: San Paolo, 2009.

KNITTER, Paul. Introdução às teologias das religiões. São Paulo: Paulinas, 2008.

KNITTER, Paul. Senza Buddha non potrei essere cristiano. Roma: Fazi Editore, 2011. 
KUNG, Hans. Teologia a caminho. Fundamentação para o diálogo ecumênico. São Paulo: Paulinas, 1999.

LÉVI-STRAUSS. Raça e história. In: LÉVI-STRAUSS. Os pensadores. 2 ed. São Paulo: Abril Cultural, 1980.

LUCCHESI, Marco. Guerras de religião? O Globo, 03 dez 2014. Disponível em:< http://noblat.oglobo.globo.com/geral/noticia/2014/12/guerras-de-religiao.html>. Acesso em: 07 dez 2014.

O’COLLINS, Gerald. On the Left of the Tiber. Leominster: Gracewing, 2013.

PANIKKAR, Raimon. Cristofania. Bologna: EDB, 1994.

PAULO VI. A evangelização no mundo contemporâneo. [Exortação Apostólica Evangelii nuntiandi]. 4 ed. Petrópolis: Vozes, 1979.

PONTIFÍCIO Conselho para o Diálogo Inter-Religioso (PCDI). Diálogo e Anúncio. Petrópolis: Vozes, 1991.

QUEIRUGA, Andrés Torres. Um Deus para hoje. São Paulo: Paulus, 1998.

QUEIRUGA, Andrés Torres. Do terror de Isaac ao abba de Jesus. Por uma nova imagem de Deus. São Paulo: Paulinas, 2001.

QUEIRUGA, Andrés Torres. Repensar a revelação. A revelação divina na realização humana. São Paulo: Paulinas, 2010.

SCHILLEBEECKX, Edward. História humana, revelação de Deus. São Paulo: Paulus, 1994a.

SCHILLEBEECKX, Edward. Universalité unique d' une figure religieuse historique nommée Jésus de Nazareth. Laval Théologique et Philosophique, Québec, v. 50, n. 2, p. 265-281, juin 1994b.

TEIXEIRA, Faustino. O diálogo inter-religioso como afirmação da vida. São Paulo: Paulinas, 1997.

TEIXEIRA, Faustino. Do diálogo ao anúncio. Reflexões sobre a declaração Dominus Iesus. Revista Eclesiástica Brasileira, Petrópolis, v. 6o, n. 240, p. 879-908, dezembro 2000.

TEIXEIRA, Faustino. Teologia e pluralismo religioso. São Bernardo do Campo: Nhanduti, 2012. 